\title{
Spectrophotometric Estimation of Aripiprazole in Tablets
}

\author{
B. K. JAYANNA* ${ }^{*}$ T. D. DEVARAJ, G. NAGENDRAPPA ${ }^{1}$ AND N. GOWDA
}

Department of Chemistry, B. N. M. Institute of Technology, Bangalore-560 070, ${ }^{1}$ Department of Post Graduate Studies And Research in Chemistry, Mysore University, Manasagangotri-570 008, India

\section{Jayanna, et al.: Spectrophotometric Estimation of Aripiprazole}

\begin{abstract}
A simple, sensitive and rapid spectrophotometric method has been developed for the determination of aripiprazole in pharmaceutical formulations. The proposed method is based on the oxidation of drug with $\mathrm{N}$-bromosuccinimide and unreacted $\mathrm{N}$-bromosuccinimide bleaches the blue color of methylene blue and is measured at $663 \mathrm{~nm}$. The increase in absorbance is directly proportional to the aripiprazole concentration and obeys Beer-Lambert's law in the range of $5-20 \mu \mathrm{g} / \mathrm{ml}$. The molar absorptivity and Sandell's sensitivity, of the method were found to be $1.4906 \times 10^{4} \mathrm{I} / \mathrm{mol} / \mathrm{cm}, 0.0300 \mu \mathrm{g} / \mathrm{cm}^{2}$, respectively. No interference was observed from excipients commonly found in tablets.
\end{abstract}

Key words: Aripiprazole, methylene blue, $N$-bromosuccinimide, spectrophotometry

Aripiprazole, chemically known as spectrometry ${ }^{[5,6]}$, HPLC-MS ${ }^{[7]}$, column switching 7-\{4-[4-(2,3-dichloro-phenyl)piperazin-1-yl] HPLC ${ }^{[8]}$, gas chromatography-mass spectrometry butoxy $\}$-3,4-dihydroquinolin-2(1H)-one, is an antipsychotic and antidepressant agent used in the treatment of schizophrenia, schizoaffective disorders, bipolar disorder and in the adjuvant therapy. A few analytical techniques such as high performance liquid chromatography (HPLC) with ultraviolet (UV) detection ${ }^{[1]}$, liquid chromatography tandemmass spectrometry (LC-MS/MS) $)^{[2,3]}$, HPLC with tandem mass spectrometry ${ }^{[4]}$, ultra performance liquid chromatography (UPLC) with tandem mass $(\mathrm{GC}-\mathrm{MS})^{[9]}$, linear scan voltammetry ${ }^{[10]}$, capillary electrophoresis ${ }^{[11]}$ and spectrophotometry ${ }^{[12]}$ have been developed for the determination of aripiprazole in pharmaceutical samples and biological fluids. These

This is an open access article distributed under terms of the Creative Commons Attribution-NonCommercial-ShareAlike 3.0 License, which allows others to remix, tweak, and build upon the work non-commercially, as long as the author is credited and the new creations are licensed under the identical terms. 
methods are tedious, require highly sophisticated instrumentation for routine analysis but are amply sensitive.

UV/Vis spectrophotometer of Systronics Model 117 with $10 \mathrm{~mm}$ matched quartz cells were used for absorbance measurement. Aripiprazole was received from Jubilant Organosys Ltd., Nanjangud, Mysore, India, as a gift sample. Tablets, Arip-MT $15 \mathrm{mg}$ (aripiprazole; $15 \mathrm{mg} /$ tablet) of Torrent Pharmaceuticals Ltd., Asprito $10 \mathrm{mg}$ (aripiprazole; $10 \mathrm{mg} /$ tablet) of Intas Pharmaceuticals Ltd., Arive $20 \mathrm{mg}$ (aripiprazole; $20 \mathrm{mg} /$ tablet) of Cadila Pharmaceuticals Ltd., were purchased from a local pharmacy. $N$-bromosuccinimide (Merck, Mumbai, India) and methylene blue (S. D. Fine-Chem., Mumbai, India) were used for the experiment.

Standard stock solution of aripiprazole $(100 \mu \mathrm{g} / \mathrm{ml})$ was prepared by dissolving $10 \mathrm{mg}$ of aripiprazole in acetonotrile and diluted to $100 \mathrm{ml}$ with distilled water. $\mathrm{N}$-bromosuccinimide $(0.0067 \mathrm{~mol} / \mathrm{l})$ and methylene blue $(0.031 \mathrm{~mol} / \mathrm{l})$ were prepared by dissolving 120 mg of $N$-bromosuccinimide and $1000 \mathrm{mg}$ of methylene blue, respectively in distilled water and diluted to 100 $\mathrm{ml}$.

Different concentrations of the standard aripiprazole solution $(5.0-20 \mu \mathrm{g} / \mathrm{ml})$ were transferred into a series of $10 \mathrm{ml}$ volumetric flasks. To each flask, $\mathrm{N}$-bromosuccinimide $(0.0067 \mathrm{~mol} / \mathrm{l})$ and $0.5 \mathrm{ml}$ of methylene blue $(0.031 \mathrm{~mol} / \mathrm{l})$ solutions were added with constant shaking. Then, the volume was made up to the mark with distilled water and absorbance was measured at $663 \mathrm{~nm}$ against reagent blank.

The calibration curve was constructed by recommended procedure as shown in fig. 1. Beer-Lambert's is obeyed over the aripiprazole concentration range of 5-20 $\mu \mathrm{g} / \mathrm{ml}$. The optical characteristics such as Sandell's sensitivity, molar absorptivity and other parameters are evaluated in Table 1.

The precision and accuracy of the method was checked by hauling out repeatability in the same day (intraday) and intermediate on two consecutive days (interday) in three replicates. The repeatability and intermediate precision was performed at three concentration levels such as 5, 10 and $15 \mu \mathrm{g} / \mathrm{ml}$. The amount, relative error percentage $(\% \mathrm{RE})$ and relative standard deviation (\%RSD) were found to be $4.96,0.67,1.17 ; 9.93,0.2$, 0.57 and $15.03,0.2,0.38$, respectively for repeatability and 4.93, 1.4, 1.17; 9.8, 2.0, 1.02 and 14.83, 1.13, 0.39, respectively for intermediate precision. The relative standard deviation percentage and relative error

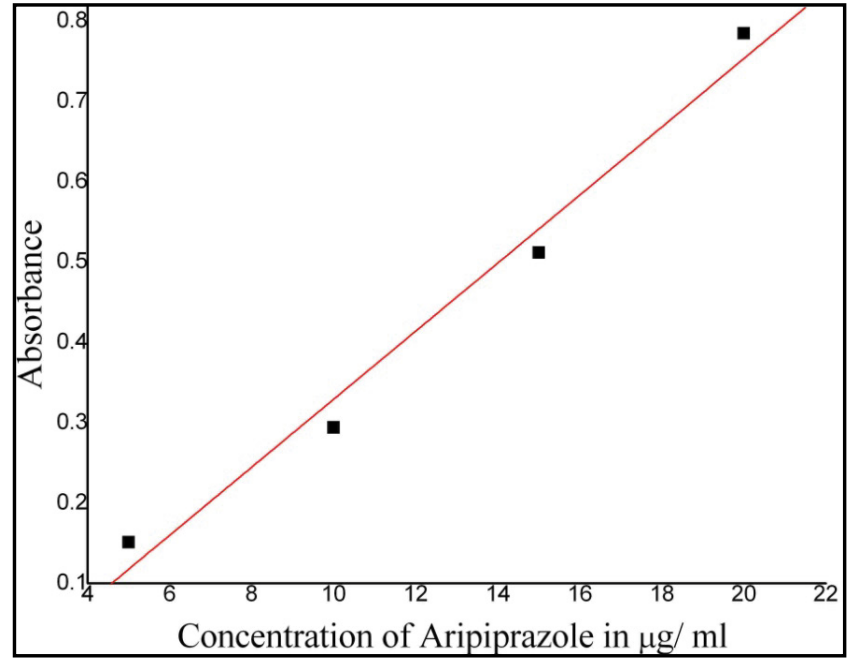

Fig. 1: Calibration graph of aripiprazole.

Aripiprazole $(5-20 \mu \mathrm{g} / \mathrm{ml})+1.0 \mathrm{ml}$ of $N$-bromosuccinimide $(0.0067 \mathrm{~mol} / \mathrm{l})+0.5 \mathrm{ml}$ of methylene blue $(0.01 \%)+$ diluted to 10 $\mathrm{ml}$ with distilled water. The calibration curve for aripiprazole was prepared and linear relationships between absorbance and concentration held over range of 5 to $20 \mu \mathrm{g} / \mathrm{ml}$.

TABLE 1: OPTICAL CHARACTERISTICS OF THE PROPOSED PROCEDURE

\begin{tabular}{lc}
\hline Parameters & Proposed method \\
\hline Color & Blue \\
$\lambda_{\text {max }}, \mathrm{nm}$ & 663 \\
Stability & $1 \mathrm{~h}$ \\
Beer's law limit $(\mu \mathrm{g} / \mathrm{ml})$ & $5-20$ \\
Molar absorptivity $\left(\mathrm{mol}^{-1} \mathrm{~cm}^{-1}\right)$ & $1.4906 \times 10^{4}$ \\
Sandel sensitivity $\left(\mu \mathrm{g} \mathrm{cm}^{-2} / 0.001 \mathrm{~A}\right)$ & 0.0300 \\
Correlation coefficient & 0.99069 \\
Regression equation slope $(\mathrm{b})$ & $0.0424-0.0945$ \\
intercept $(\mathrm{a})$ & \\
Standard deviation $(\mathrm{SD})$ & 0.04607 \\
\hline
\end{tabular}

percentage valves were below $2 \%$ symptomatic of high precision and good accuracy of the proposed method.

The ruggedness of the method was illustrated for the same concentration $10 \mu \mathrm{g} / \mathrm{ml}$ using two different spectrophotometer models (UV spectrophotometer Model-117, Systronics and UV spectrophotometer Model-1800, Hitachi) and by two analysts in the same laboratory. Amount and relative standard deviation in both instances were found to be $9.93,0.57 ; 10.06$, 0.58 and $9.86,0.59,10.0,1.0$. The low relative standard deviation percentage valves in both instances suggesting ruggedness of the method. The proposed method does not does not involve any reagents to develop color and free from extraction procedure, hence the method is more robust.

The interference effects was studied by determining $10 \mu \mathrm{g} / \mathrm{ml}$ of aripiprazole in presence of different 
excipients such as cellulose, starch, talc and lactose at different concentrations present in tablet formulation. The results signified that there is no interference from any excipients.

For the investigation of pharmaceutical formulations, twenty tablets of aripiprazole were weighed and powdered. The powder equal to $10 \mathrm{mg}$ of aripiprazole was weighed and dissolved in acetonitrile. The residue was filtered into $100 \mathrm{ml}$ flask and volume was made up to the mark with distilled water. An appropriate dilute solution was analyzed according to the suggested procedure. The amount and relative standard deviation (\%RSD) for the formulations Asprito $10 \mathrm{mg}$, Arip-MT $15 \mathrm{mg}$ and Arive $20 \mathrm{mg}$ were found to be 9.93, 0.57; $14.96,1.39$ and 20.06, 0.25 respectively.

The proposed method is based on the oxidation of drug with $N$-bromosuccinimide. Bromine atom of $\mathrm{N}$-bromosuccinimide reacts with aripiprazole to from bromo compound presumably in the dichloro benzene ring. Unreacted $N$-bromosuccinimide then reacts with methylene blue leading to decolorization due to loss of conjugation in the heterocyclic ring. The absorbance is measured at $663 \mathrm{~nm}$ is linear with the concentration of aripiprazole and directly proportional to the amount of $\mathrm{N}$-bromosuccinimide reacting with aripiprazole.

The proposed method is found to be simple, rapid, and free from use of organic solvents and extraction; requires neither heating nor extraction nor $\mathrm{pH}$ maintenance. Drug can be determined with assurance and with a good precision and accuracy. The method uses easily accessible reagents and no interference was observed from excipients commonly found in tablets. Hence, the proposed method can be used for the determination of aripiprazole in tablets.

\section{Financial support and sponsorship:}

Nil.

\section{Conflicts of interest:}

There are no conflicts of interest.

\section{REFERENCES}

1. Shimokawa Y, Akiyama H, Kashiyama E, Koga T, Miyamoto G. High performance liquid chromatographic methods for the determination of aripiprazole with ultraviolet detection in rat plasma and brain: application to the pharmacokinetic study. $\mathrm{J}$ Chromatogr B 2005;821:8-14.

2. Kubo M, Mizooku Y, Hirao Y, Hirao Y, Osumi T. Development and validation of an LC-MS/MS method for the quantitative determination of aripiprazole and its main metabolite, OPC14857, in human plasma. J Chromatogr B 2005;822:294-9.

3. Song M, Xu X, Hang T, Wen A, Yang L. Development of an LC-MS/MS method for the simultaneous quantification of aripiprazole and dehydroaripiprazole in human plasma. Anal Biochem 2009;385:270-7.

4. Kirchherr H, Kuhn-Velten WN. Quantitative determination of forty-eight antidepressants and antipsychotics in human serum by HPLC tandem mass spectrometry: a multi-level, singlesample approach. J Chromatogr B 2006;843:100-13.

5. Patel DP, Sharma P, Sanyal M, Shrivastav PS. SPE-UPLCMS/MS method for sensitive and rapid determination of aripiprazole in human plasma to support a bioequivalence study. J Chromatogr B 2013;925:20-5.

6. Li KY, Zhou YG, Ren HY, Wang F, Zhang BK, Li HD. Ultra-performance liquid chromatography-tandem mass spectrometry for the determination of atypical antipsychotics and some metabolites in in vitro samples. J Chromatogr B 2007;850:581-5.

7. Choong E, Rudaz S, Kottelat A, Guillarme D, Veuthey JL, Eap CB. Therapeutic drug monitoring of seven psychotropic drugs and four metabolites in human plasma by HPLC-MS. J Pharm Biomed Anal 2009;50:1000-8.

8. Akamine $\mathrm{Y}$, Norio YF, Kojima M, Inoue Y, Uno T. A sensitive column- switching HPLC method for aripiprazole and dehydroaripiprazole and its application to human pharmacokinetic studies. J Sep Sci 2010;33:3292-8.

9. Huang $\mathrm{HC}$, Liu $\mathrm{CH}$, Lan $\mathrm{TH}, \mathrm{Hu} \mathrm{TM}$, Chiu $\mathrm{HJ}$, Wu YC, et al. Detection and quantification of aripiprazole and its metabolite, dehydroaripiprazole, by gas chromatographymass spectrometry in blood samples of psychiatric patients. $\mathrm{J}$ Chromatogr B 2007;856:57-61.

10. Merli D, Dondi D, Ravelli D, Tacchini D, Profumo A. Electrochemistry and analytical determination of aripiprazole and octoclothepin at glassy carbon electrode. J Electroanalytical Chemistry 2013;711:1-7.

11. Tsai CJ, Yu YH, Chiu HJ, Loh EW, Wang JT, Chan CH, et $a l$. The quantitative detection of aripiprazole and its main metabolite using capillary-electro- phoresis. J Chin Med Assoc 2011;74:267-71.

12. Jain R, Kashaw SK, Rishab Jain, Mishra P, Kohli DV. Visible spectrophotometric method for the determination of aripiprazole in tablets. Indian J Pharm Sci 2011;73:74-6. 